\title{
PENGELOMPOKAN DAN PERLAKUAN SERTA KEMAMPUAN BAKAR KULIT BIJI MENTE PADA TEKNOLOGI BAKAR KULIT BIJI MENTE
}

\author{
Yohanes Benediktus Yokasing ${ }^{1}$, Amiruddin Abdullah², Antonius Pangalinan ${ }^{3}$ \\ Jurusan Teknik Mesin, Politeknik Negeri Kupang 1,2,3 \\ Jl. Adisucipto, Penfui, Kupang \\ e-mail: yohanesyokasing@yahoo.co.id ${ }^{1}$, Amiruddinabdullah90@yahoo.co.id², \\ antoniuspangalinan@yahoo.com ${ }^{3}$
}

\begin{abstract}
ABSTRAK
Biji mente berukuran kecil, sedang dan besar, kulit biji mente yang keras, dan CNSL yang ada pada kulit biji, yang bersifat racun. Kacang mente yang bermutu harus bebas dari CNSL, utuh dan tetap berwarna putih. Untuk itu dibuat Teknologi Bakar Kulit Mente yang memiliki 3 Selinder Ruang Vertikal". Untuk bahan bakar bambu prosentase CNSL terendah yakni 38,7 \%, dengan perlakuan pengukusan 13 menit, pada dimensi biji kecil, sedangkan bahan bakar daun lontar terendah pada bahan bakar 44,7\%, dengan perlakuan pengukusan 11 menit dan penjemuran selama 16 jam. Kacang mente berwarna kuning lebih banyak terjadi pada bahan bakau daun lontar. Prosentase CNSL tersedikit terdapat pada biji mente yang kecil, dibandingkan biji yang sedang, dan biji besar semakin tinggi prosentase.
\end{abstract}

Kata Kunci: Media Bakar, Kulit Biji, Kacang Mente.

\section{PENDAHULUAN}

Pengupasan kulit biji mete untuk mendapatkan kacang mente di Nusa Tenggara Timur (NTT), masih dilakukan industri rumah tangga, dan dilakukan sewaktu-waktu saja. Kesulitan mengupas gelondong mete yang dikarenakan keterbatasan teknologi. Teknologi yang digunakan yakni kacip. Kacip yang digunakan yakni kacip ceklok. Kacip yang digunakan memiliki keterbatasan, mata kacip yang berfungsi menyayat, memiliki bentuk mata mengikuti bentuk biji dan kacang secara umum dan ukuran mata kacip hanya mengikuti satu ukuran kacang mente saja, jadi tidak sesuai dengan ukuran biji yang lain.

Untuk memperoleh kacang mete utuh tidak semudah yang dibayangkan, karena kacang mete terbungkus oleh kulit mente yang keras dan tidak teratur serta adanya cashew nut shell liquid atau cnsl, yang bersifat racun oleh karena itu untuk mengupas kulit mente diperlukan alat khusus [11]. Pengupasan dilakukan dengan kacip ada yang dilakukan secara langsung tanpa adanya perlakuan biji mente, namun ada pula menggunakan perlakuan berupa penjemuran, pengukusan dan perendaman. Ada pula dilakukan dengan cara yakni mengelompokan biji mente dalam 3 kelompok ukuran. Untuk membantu mengupas biji mente dibutuhkan pengelompokan dalam tiga kelompok, besar, sedang dan kecil [12]. Upaya pengelompokan tersebut diatas belum menjawab persoalan, sampai saat ini.

Namun dari upaya-upaya diatas, prosentase tanpa perlakuan memiliki hasil yang rendahnya untuk kacang mete utuh yang diperoleh dan tercemarnya kacang mete oleh cairan kulit biji mete atau minyak laka [1]. Prosentase kacang mete utuh, yang dihasilkan oleh pengrajin rumah tangga, dan industry kecil sekitar $60-70 \%$ dengan mutu rendah [8]. . Kenyataan ini masih berlaku hingga sekarang, sehingga biji jambu mente sebagian besar dijual dalam bentuk gelondongan. Hal ini dapat dikutip melalui, Antara News, 2015, yang mengatahkan bahwa "Selama ini setelah panen, komoditas ini dijual antara daerah 
dalam provinsi yaitu ke Kabupaten Flores Timur dari Flores Timur dipasarkan keluar NTT".

Persoalan tersebut diatas belum terjawabkan karena tidak adanya kajian teknologi alternatif. Masyarakat NTT lebih condong mengadopsi teknologi dari luar NTT, karena dipengaruhi oleh tingkat pendidikan, pengalaman usahatani [3].

Untuk dapat memecahkan ketergantungan pada kacip dan kendalanya, perlu dilakukan dengan beberapa cara pengupasan yakni cara pukul, cara kacip belah, dan kacip ceklok". Hal ini dikarenakan pengupasan kacang mente dituntut untuk mendapatkan kualitas kacang mente yang baik, yakni terbebas dari CNSL, utuh, dan warnanya tetap putih seperti bawaan.

Untuk itu dibutuhkan teknik pengupasan alternatif yang menjadi solusi tersebut diatas. Penggupasan alternatif seperti pembakaran yang didahului perlakukan berupa penjemuran atau pengukusan dan penjemuran lebih menguntungkan, karena kacang mete tidak bersentuhan dengan mata kacip, dan kulit gelondong mete tidak tersayat sehingga CNSL tidak terkontaminasi dengan kacang mete.

Maka perlunya dilakukan kajian dengan judul, "Pengelompok, Perlakuan dan Kemampuan Bakar Kulit Biji Mente pada Teknologi Bakar Kulit Biji Mente". Pengupasan dengan cara dipukul merupakan cara tradisional, yang didahului dengan pembakaran gelondongan mete. Cara ini memiliki kekurangannya yakni pembakaran dengan suhu atau lamanya waktu pembakaran menyebabkan kacang mete matang atau berubah warna dari putih ke coklat atau warna lainnya (Survey lapangan, 2015). Untuk itu perlunya dikaji pengaruh bahan bakar, dimensi ruang bakar, dan waktu pembakaran serta perlakuan terhadap kualitas kacang mete.

\section{TINJAUAN PUSTAKA}

\section{Pengolahan Pasca panen dan Kualitas Kacang Mete}

Penanganan pascapanen biji mente adalah cara pengupasan untuk memperoleh bijinya secara utuh. Biji mente yang memiliki kulit biji yang keras, bentuk biji yang tidak seragam dan kulit biji yang mengandung cashew nut shell liquid atau cnsl, yang bersifat racun, untuk mempertahankan kualitas biji mente dibutuhkan tahapan-tahapan penanganan pasaca panen sebagai berikut:

1. Pengeringan Biji Mente

Pengeringan dilakukan hingga kadar airnya mencapai $5 \%$, lama pengeringan 1- 2 hari.

2. Penyimpanan Mete Gelondong

Mete yang disimpan harus yang telah kering sempurna, bagi yang belum kering akan mengakibatkan bijinya berwarna coklat. Penyimpanan bisa dengan cara curahan (baik) atau kemasan karung.

3. Pengupasan Kulit Mete Gelondong Pengupasan biji mente, dapat dilakukan dengan beberapa cara yakni dengan cara mekanis yang kompleks yaitu:

1) Cara Pukulan

Mula-mula biji mete digoreng (baik denga pan terbuka maupun dengan pemanasan CNSL). Kemudian disiram dengan air, atau diberi abu, srbuk gergaji dan lain-lain, lalu metenya diletakan diatas landasan (bagian perut menghadap keatas dan bagian punggng kebawah). Pemukulan dilakukan dari atas dengan sebuah kayu terhadap mete satu persatu. Bagi yang terampil bias mencapai $5-8 \mathrm{~kg} / \mathrm{hari}(8 \mathrm{jam})$.

2) Cara Kacip Belah

Mete gelondong diletakkan diatas mata kacip dengan bagian perut menghadap keatas, mata kacip diarahkan ke biji mete dan ditekan, biji tersayat dan terbelah dua. Kacang mete dikeluarkan dari belahan pakai pisau/paku yang ujungnya pipih. 
3) Cara dengan Kacip Ceklok

Metenya diletakan diatas landasan dengan bagian perut menghadap keatas. Kacip diturunkan, ditekan sehingga mengiris kulit gelondong. Setelah itu ditekan lagi kearah bawah ke samping luar. Pengupasan akan terjadi sepanjang garis belahan, kacangnya dicongkel dengan pisau untuk melepaskan dari belahan kulit.

\section{Pengeringan Biji}

Pengeringan dilakukan setelah biji dikupas, tujuannya mengurangi kadar air-nya hingga $3 \%$ dan untuk mempermudah pengupasan kulit ari mete (testa). Pengeringan bias dengan mata hari atau dengan cara mekanis. Pengeringan dengan sinar matahari dilakukan hingga kulit arinya dapat dikelupas dengan tangan. Keuntungannya biji tidak gosong dan kualitas baik. Kelemahannya kadar airnya lebih $3 \%$ biji sangat rapuh (mudah hancur), dengan cara mekanis dilakukan pada suhu optimum 700c selama $4-8$ jam, kualitasnya baik dengan kadar air $\pm 3 \%$.

5. Pengupasan Kulit Biji Mete (kulit ari)

Pengupasan kulit ari dilakukan setelah dikeringkan, pengupsan dapat secara manual, cara lain yang dilakukan oleh para petani yaitu proses gabungan antara pengorengan bersama-sama dengan pengupasan. Pada cara mekanis biji metenya perlu dilembabkan kembali hingga mencapai kadar air $5 \%$ (cara ini tidak dilakukan petani didaerah).

6. Sortasi dan Granding / Pengelompokan Tingkat Dasar sotir dan granding ialah keadaan, ukuran serta warna, berdasarkan keadaan dapat dibedakan 6 golongan yaitu ; biji utuh/whole; biji sedikit sedikit utuh/butts; biji belh/splits; remukan halus/baby bits. Gelondong yang didapat berdasarkan warna yaitu biji putih/white kernels; biji agak putih/fancy; biji 1/2 gosong/desserts; dan gosong/scarched. Beberapa standar menurut besar dan warna biji yang ada dalam perdagangan antara lain;
1) White wholes (biji utuh seluruhnya, tiap ons berisi 100-200 biji, kerusakan akibat pegangkutan maksimal $10 \%$ dan bebas kotoran)

2) Butts (sebagian kecil bijinya sudah pecah); white splits (biji pecah/terbelah menjadi 2 bagian).

3) Large white pieces (biji pecah dengan ukuran diatas $0,4-0,5 \mathrm{~cm}$ )

4) Scorched grades (standar yang paling rendah biji terbakar ringan)

\section{Pengemasan}

Pengemasan perlu dilakukan karena bijibijinya mudah sekali rusak. Kemasannya dapat berupa peti/kaleng, plastic kemas dalam keadaan tanpa udara.

\section{Struktur Biji Mente}

Biji mente berasal dari buah mente, yang menyatu pada buah itu sendiri [10]. Buah mente terjadi dari persarian yang terjadi, lambat laun terbentuk buah yang terdiri atas, dua bagian, yaitu:

1. Buah semu yang berdaging dan banyak mengandung air. Buah semu ini adalah tangkai buah yang membesar seperti daging buah yang normal.

2. Buah yang benar berupa buah batu berbentuk ginjal dan terdiri atas:

1) Kulit yang keras dan mengandung minyak

2) Biji berbelah dua.

Buah yang benar berupa buah batu tidak lain adalah biji jambu mente. Biji jambu menteh ini memiliki struktur biji yang terdiri dari:

1. Kulit biji, kulit biji merupakan lapisan terluar yang keras dan mengandung minyak

2. Kulit ari yakni kulit yang berada didalam kulit biji, yang menyelimuti kacang mente

3. Kacang mente yakni biji terdalam, yang mudah dibelah dua dan mengandung kandungan hiegenis yang tinggi 


\section{Ukuran Biji Mente}

Untuk kemudahkan pengupasan dan tetap mengutamakan keutuhan kacang mente, biji mente dikelompokan dalam 3 ukuran (besar, sedang dan kecil)". Kemudahan merancang kacip cukup dibagi 2 kelompok saja, yakni, 1) Biji besar memiliki ukuran rata-rata, panjang (a) 28 $\mathrm{mm}$, lebar (b)19,9 dan tebal (c)13,4 mm, dengan ketebalan kulit 2,3 mm dan (2) biji kecil memiliki ukuran rata-ratat panjang (a) 24,6 $\mathrm{mm}$ lebar (b)16.5 $\mathrm{mm}$ dan tebal (c) $13,7 \mathrm{~mm}$, serta untuk tebal kulit $2 \mathrm{~mm}$ [12].

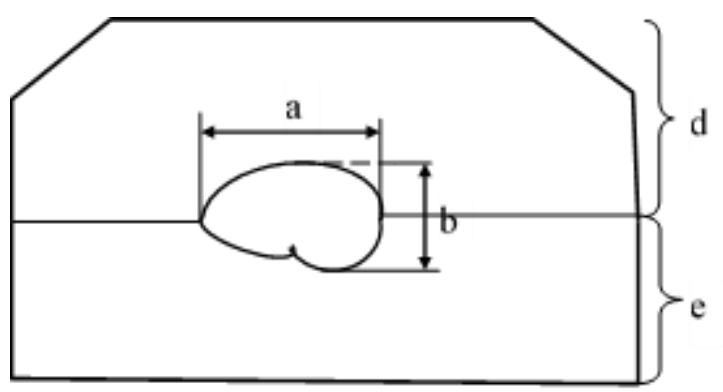

Gambar 1. Desain Mata kacip

Catatan; Ukuran sesaui dengan dimensi kacang mente tersebut diatas

Keterangan:

a: panjang kacang mente

b: lebar kacang mente

c: tebal kacang mente

d: mata kacip bagian atas, lebar mata atas diperoleh dari $b / 2$

e: mata kacipbagian bawah, lebar mata bawah diperoleh dari $b / 2$

\section{Teknik Pengolahan dan Perlakuan Lainnya di NTT}

Masyarakat NTT dalam pengupasan biji mente sebagai berikut, pengukusan gelondong mete sebelum dikupas dengan kacip ceklok dilakukan untuk meningkatkan prosentase kacang mete utuh dan kualitasnya serta rasa kacang tidak berubah. Pengukusan gelondong mete pada air mendidih selama menit dan dihamparkan satu malam menghasilkan prosentase kacang mete utuh lebih tinggi dibandingkan pola lama petani dengan tanpa perlakuan [7].

\section{Kemampuan Nyala (bakar) Kayu}

Bahan bakar memiliki kemampuan bakar dan menghasilkan nyala yang berbeda beda. Hal ini berlaku pula pada bahan bakar kayu, seperti daun kelapa, daun tuak, bila bambu dan lain-lainnya (bahan bakar padat). Pembakaran tergantung dari bahan yang dibakar dan oksigen sebagai media bakar. Bahan bakar padat diantara kayu, sampah, ampas tebu, kulit kelapa, kulit biji teh, dan lain-lain. Bahan bakar padat mengandung unsurunsur antara lain, zat arang atau karbon (C), Hidrogen $(\mathrm{H})$, zat asam atau Oksigen $(\mathrm{O})$, zat lemas atau Nitrogen $(\mathrm{N})$, Belerang (S), Abu dan Air, yang semuanya itu terikat dalam satu perseyawaan kimia. Pada umumnya temperatur penyalaan makin tinggi bila susunan bahan bakar makin sederhana. Kecepatan pembakaran, tergantung pada penguapan uap air dan zatzat penguap tersebut tergantung dari besar kecilnya butir-butiran bahan bakar, akan berlangsung kira-kira selama lima menit [4].

Kemampuan membakar pun bergantung pada jumlah kayu yang dipakai, laju pembakaran, kelembaban kayu, besar kecilnya kayu, serta tambahan bakar lainnya. Menurut T. Istirokhatun, 2011 et all mengatahkan bawah, "Hubungan kelembaban kayu terhadap konsentrasi PM 2,5 memiliki korelasi yang jauh dari 1 yaitu $\mathrm{R} 2=0,04$, hal ini dapat terjadi karena banyak faktor di 10 sampel, seperti jumlah kayu yang dipakai, laju pembakaran, kelembaban kayu, besar kecilnya kayu, serta tambahan bakar lainnya.

\section{METODE PENELITIAN}

Penelitian ini dilakukan di Lab. Teknologi Mekanik, Lab. Pengujian Material, Jurusan Teknik Mesin, Politeknik Negeri Kupang, yang meliputi beberapa kegiatan yakni perancangan, perencanaan dan pembuatan teknologi, serta dilakukan kajian teknologi. Setelah mendapatkan teknologi dilanjutkan dengan melakukan kajian. Rancangan penelitian yang 
digunakan adalah rancangan acak kelompok (RAK) pola faktorial dengan beberapa variabel yang dikaji. Untuk mengetahui kemampuan bahan bakar, dimensi ruang bakar (bentuk dan ukuran) dan perlakuan terhadap warna kacang mete dan utuh tidaknya kacang mente, maka digunakan estimasi yang dinyatakan:

$$
\mathrm{A}+B+T=\mathrm{y}
$$

Pers. 1) Bahan Bakar (A), perlakuan (B), dan lama pembakaran (T) akan mempengaruh kualitas kacang mete (y) Keterangan:

$\mathrm{A}=$ Bahan bakar; $\mathrm{B}=$ perlakuan; $\mathrm{T}=$ time, $\mathrm{y}=$ kualitas kacang mete (kacang tidak kuning atau hitam tetap putih).

Ada beberapa variabel yang dikaji dalam penelitian ini yakni, variabel bebas (independent), yang terdiri dari :

1. Bahan Bakar, bahan bakar yang digunakan yakni batang bambu dan daun lontar.

2. Perlakukan terhadap gelondong mete, dengan cara, dijemur, dikukus dan dikukus. Biji mente yang mengalami perlakuan berupa penjemuran selama 1, 2 dan 3 hari. Untuk biji mente mengalami perlakuan kukus dan jemur yakni dikukus selama 9 menit, 11 menit dan 13 menit, dan dijemur selama 1 hari, 2 hari dan 3 hari

3. Waktu pembakaran selama 60 detik.

Variabel tak bebas (dependent) yakni kualitas kacang mete yang diamati yakni warna. Warna kacang mente yang putih merupakan warna bawaan dari gelondong biji mente, sedangkan warna kuning atau hitam mengalami kerusakan akibat dibakar atau rusak.

\section{Teknik Pengukuran CNSL}

Mempertimbangkan keterbatasan sarana dan kebutuhan akan teknologi kupas biji mente, maka perancangan teknik pengukuran terhadap kulit mente hasil pembakaran dilakukan dengan:

Pemetaan dimensi kulit biji pada beberapa bagian, pengamatan kondisi basah/tidaknya kulit mente yang dilakukan secara visual dan perhitungan prosentase terhadap kondisi kulit. Untuk mempermudah pengukuran kondisi kulit (basah/tidaknya) dibagi dalam 3 jenis yakni:

1. Basah artinya keseluruhan kulit ada minyak = nilainya 100

2. Setengah basah atau ada yang kering $=$ nilai 50

3. Tidak basah $/$ kering $=$ nilai 0

Keterangan: basah: kulit biji yang diamati benar-benar basah keseluruhan, setengah basah: kulit biji yang diamati ada yang basah dan ada yang kering, kering: kulit biji yang diamati tidak ada minyak,

Teknik pengukuran sebagai berikut:

1) Kulit biji terlebih dipetakan menjadi 8 bagian kulit (direncanakan)

2) Lakukan pengamatan visual, dengan pengamatan kondisi kulit.

3) Perhitungan prosentase basah Basah $=$ (kondisi kulit berminyak CNSL $x$ jumlah petaan kulit yang basah) $)_{1}+$ (kondisi kulit berminyak CNSL $x$ jumlah petaan kulit yang basah) $2+$ x 100 prosentase

\section{HASIL DAN PEMBAHASAN}

\section{Kajian Sebelumnya}

Kajian sebelumnya oleh Wawan Lukman (2005), persentase kacang mete utuh, dari hasil kupasan yang optimal dapat diperoleh dari gelondong mete yang telah dijemur 3 hari pada kondisi cahaya matahari cerah, dengan perlakuan berupah pengukusan dan tanpa pengukusan, tampak tabel berikut ini, 
Tabel 1. Rata-rata Jumlah Gelondong Mete, Presentase Kacang Utuh, Bobot Kacang, dan Lamanya Pengkacipan, FloresTimur, NTT

\begin{tabular}{|c|c|c|c|c|c|}
\hline \multirow{3}{*}{ Bahan Bakar } & \multicolumn{2}{|c|}{ Perlakuan Biji Mente } & \multirow{3}{*}{$\begin{array}{c}\text { Presentase } \\
\text { CNSL pada } \\
\text { Kulit Mente } \\
(\%) \\
\end{array}$} & \multirow{2}{*}{\multicolumn{2}{|c|}{ Kacang Mete }} \\
\hline & \multirow{2}{*}{$\begin{array}{l}\text { Kukus } \\
\text { (menit) } \\
\end{array}$} & \multirow{2}{*}{$\begin{array}{l}\text { Jemur } \\
\text { (Jam) } \\
\end{array}$} & & & \\
\hline & & & & Warna & Utuh/Pecah \\
\hline \multirow[t]{9}{*}{ Daun Lontar } & - & 8 & 78,3 & puth & utuh \\
\hline & - & 16 & 74,6 & putih & utuh \\
\hline & - & 24 & 65,6 & putih & utuh \\
\hline & 9 & 8 & 70,6 & puth & utuh \\
\hline & 11 & 8 & 63,6 & puth & utuh \\
\hline & 13 & 8 & 48 & putih & utuh \\
\hline & 9 & 16 & 64 & puth & utuh \\
\hline & 11 & 16 & 61,3 & putih & utuh \\
\hline & 13 & 16 & 44,6 & $\begin{array}{l}\text { puth/ } \\
\text { kuning }\end{array}$ & utuh \\
\hline \multirow[t]{9}{*}{ Batang Bambu } & - & 8 & 62,6 & puth & utuh \\
\hline & - & 16 & 68 & putih & utuh \\
\hline & - & 24 & 59 & putih & utuh \\
\hline & 9 & 8 & 65 & puth & utuh \\
\hline & 11 & 8 & 57 & puth & utuh \\
\hline & 13 & 8 & 42,6 & puth & utuh \\
\hline & 9 & 16 & 55,3 & putih & utuh \\
\hline & 11 & 16 & 54,3 & puth & utuh \\
\hline & 13 & 16 & 40 & putih & utuh \\
\hline
\end{tabular}

Kajian Terhadap Teknologi Bakar Kulit Mente (TBKM)

Kajian ini dilakukan; bahan bakar, perlakuan, dan ukuran biji yang dikelompokan pada besar, sedang dan kecil terhadap prosentase CNSL yang ada pada kulit kacang mente dan mengamati hasil kacang mente (warna dan utuh tidaknya). Penelitian dilakukan untuk mencapai variabel yang direncanakan. Sesuai variabel yang dirancang, biji mente dikukus pada suhu $100^{\circ} \mathrm{C}$ selama 9,11 dan 13 menit, dan dijemur 8 jam, 16 jam.

Data yang diperoleh sebagai berikut,

\section{Biji Mente Besar}

Tabel 2. Rekapan Kinerja Teknologi Bakar Kulit Biji Mente, untuk Dimensi Besar

\begin{tabular}{|c|c|c|c|c|c|}
\hline \multirow{3}{*}{ Bahan Bakar } & \multicolumn{2}{|c|}{ Perlakuan Biji Mente } & \multirow{3}{*}{$\begin{array}{c}\text { Presentase } \\
\text { CNSL pada Kulit } \\
(\%) \\
\end{array}$} & \multirow{2}{*}{\multicolumn{2}{|c|}{ Kacang Mete }} \\
\hline & \multirow{2}{*}{$\begin{array}{l}\text { Kukus } \\
\text { (menit) } \\
\end{array}$} & \multirow{2}{*}{$\frac{\text { Jemur }}{\text { (Jam) }}$} & & & \\
\hline & & & & Warna & Utuh/Pecah \\
\hline \multirow[t]{9}{*}{ Daun Lontar } & - & 8 & 78,3 & putih & utuh \\
\hline & - & 16 & 74,6 & putih & utuh \\
\hline & - & 24 & 65,6 & putih & utuh \\
\hline & 9 & 8 & 70,6 & puth & utuh \\
\hline & 11 & 8 & 63,6 & puth & utuh \\
\hline & 13 & 8 & 48 & putih & utuh \\
\hline & 9 & 16 & 64 & putih & utuh \\
\hline & 11 & 16 & 61,3 & puth & utuh \\
\hline & 13 & 16 & 44,6 & $\begin{array}{l}\text { putihl } \\
\text { kuning }\end{array}$ & utuh \\
\hline \multirow[t]{9}{*}{ Batang Bambi } & - & 8 & 62,6 & puth & utuh \\
\hline & - & 16 & 68 & putih & utuh \\
\hline & - & 24 & 59 & puth & utuh \\
\hline & 9 & 8 & 65 & puth & utuh \\
\hline & 11 & 8 & 57 & putih & utuh \\
\hline & 13 & 8 & 42,6 & putih & utuh \\
\hline & 9 & 16 & 55,3 & puth & utuh \\
\hline & 11 & 16 & 54,3 & puth & utuh \\
\hline & 13 & 16 & 40 & putih & utuh \\
\hline
\end{tabular}

Daun lontar sebagai media bakar yang digunakan membakar biji mente, dengan perlakuan biji mente dijemur 8 jam menghasilkan prosentase CNSL pada kulit biji mente mencapai $78,3 \%$, kacang mente yang dihasilkan berwarna putih dan utuh, untuk penjemuran selama 24 jam, menghasilkan prosentase CNSL pada kulit mente menurun menjadi $65,6 \%$, kacangnya tetap berwarna putih dan utuh.

Bahan bakar yang sama dilanjutkan dengan perlakuan berupa pengukusan selama 9 menit dan dijemur selama 8 jam, memberikan prosentase minyak CNSL sebesar 70,6\%, sedangkan untuk perlakuan pengukusan selama 13 menit dan lama penjemuran yang sama (8 jam) 
memberikan, minyak CNSL yang masih tertinggal pada kulit biji mente menjadi $48 \%$ saja. Selanjutnya dengan bahan bakar yang sama dilakukan perlakuan berupa peningkatan penjemuran selama 16 jam setelah dilakukan pengukusan menunjukan bahwa, pengukusan selama 9 menit, 11 menit, dan 13 menit, secara berturut turut menghasilkan $64 \%, 61,3 \%$ dan $44, \%$, kulit biji mente masih mengantung CNSL.

Jika dibandingkan dengan bahan bakar batang bambu, perlakuan hanya penjemuran saja, menunjukan penjemuran 8 jam, CNSL yang masih ada pada kulit biji mente $62,6 \%$, perlakuan penjemuran 16 jam, CNSL pada kulit biji yang dibakar sebanyak $68 \%$, sedangkan penjemuran ditingkatkan menjadi 24 jam, CNSL yang masih tersisa pada kulit mengalami penurunan menjadi 59\%. Perlakuan tambahan berupah pengukusan, untuk pengukusan selama 9 menit dan dilakukan penjemuran 8 jam, CNSL $65 \%$, pengukusan 13 menit dengan penjemur 8 jam, CNSL yang terkadung menurun menjadi 42,6 \%. Dilakukan peningkatan waktu penjemuran menjadi 16 jam, daidapatkan untuk pengukusan 9 menit, CNSL mencapai 65,3\%, 11 menit CNSL mencapai 54,3 \% dan 13 menit, CNSL menurun menjadi $40 \%$.

Kacang mente yang diperoleh dengan perlakuan tersebut hanya pada daun lontar ada yang kuning, terjadi pada perlakuan pengukusan selama 13 menit dan penjemuran 16 jam, dan kacang mentenya utuh, sedangkan pada bahan bakar batang bambu kacang mente tetap putih dan utuh.

\section{Biji Mente Sedang}

Tabel 3. Rekapan Kinerja Teknologi Bakar Kulit Biji Mente, untuk Dimensi

Sedang

\begin{tabular}{|c|c|c|c|c|c|}
\hline \multirow{3}{*}{ Bahan Bakar } & \multicolumn{2}{|c|}{ Perlakuan Biji Mente } & \multirow{3}{*}{$\begin{array}{l}\text { Presentase CNSL } \\
\text { pada Kulit Mente } \\
(\%)\end{array}$} & \multirow{2}{*}{\multicolumn{2}{|c|}{ Kacang Mete }} \\
\hline & \multirow{2}{*}{$\begin{array}{l}\text { Kukus } \\
\text { (menit) }\end{array}$} & \multirow{2}{*}{$\begin{array}{l}\text { Jemur } \\
\text { (Jam) } \\
\end{array}$} & & & \\
\hline & & & & Warna & Utuh/Pecah \\
\hline \multirow[t]{9}{*}{ Daun Lontar } & - & 8 & $7 \overline{75,3}$ & putih & Utuh \\
\hline & - & 16 & 73 & puth & utuh \\
\hline & - & 24 & 74 & putih & utuh \\
\hline & 9 & 8 & 65,3 & puth & utuh \\
\hline & 11 & 8 & 73,3 & putih & utuh \\
\hline & 13 & 8 & 64,7 & puth & utuh \\
\hline & 9 & 16 & 50 & kuning & utuh \\
\hline & 11 & 16 & 62 & kuning & utuh \\
\hline & 13 & 16 & 58,7 & puth & utuh \\
\hline \multirow[t]{9}{*}{ Batang Bambu } & - & 8 & 44 & puth & utuh \\
\hline & - & 16 & 62,3 & putih & utuh \\
\hline & - & 24 & 67,7 & puth & utuh \\
\hline & 9 & 8 & 57,7 & puth & utuh \\
\hline & 11 & 8 & 42,3 & kuning & utuh \\
\hline & 13 & 8 & 52,3 & putih & utuh \\
\hline & 9 & 16 & 54,3 & puth & utuh \\
\hline & 11 & 16 & 52,3 & puth & utuh \\
\hline & 13 & 16 & 46 & putih & utuh \\
\hline
\end{tabular}

Pada media bakar daun lontar untuk biji sedang, dengan tanpa perlakuan biji mente dijemur 8 jam menghasilkan prosentase CNSL pada kulit biji mente 75,3 $\%$, kacang mente yang dihasilkan berwarna putih dan utuh, bahan bakar yang sama dengan perlakuan berupa pengukusan selama 9 menit dan dijemur selama 8 jam, memberikan prosentase minyak CNSL sebesar 65,3 \%, untuk perlakuan pengukusan selama 11 menit dan lama penjemuran yang sama 8 jam memberikan, minyak CNSL yang masih tertinggal pada kulit biji mente menjadi $73,3 \%$ saja. Selanjutnya dengan bahan bakar yang sama dilakukan perlakuan berupa peningkatan penjemuran selama 16 jam setelah dilakukan pengukusan menunjukan bahwa, pengukusan selama 9 menit, 11 menit, dan 13 menit, secara berturut turut menghasilkan 50\%, 62\% dan 58,7, \%, kulit biji mente masih mengantung CNSL, kondisi kacang secara bertutut-turut pula yakni kuning, kuning, putih dan semuanya utuh.

Jika dibandingkan dengan bahan bakar batang bambu, perlakuan hanya 
penjemuran saja, menunjukan penjemuran 8 jam, CNSL yang masih ada pada kulit biji mente $44 \%$, perlakuan penjemuran 16 jam, CNSL pada kulit biji yang dibakar sebanyak $62,3 \%$, sedangkan penjemuran ditingkatkan menjadi 24 jam, CNSL yang masih tersisa pada kulit mengalami penurunan menjadi 67,7\%. Perlakuan tambahan berupah pengukusan, untuk pengukusan selama 9 menit dan dilakukan penjemuran 8 jam, CNSL 57,7\%, pengukusan 13 menit dengan penjemur 8 jam, CNSL yang terkadung menurun menjadi $42,3 \%$, kacang mente berwarna kuning, Dilakukan peningkatan waktu penjemuran menjadi 16 jam, didapatkan untuk pengukusan 9 menit, CNSL mencapai 54,3\%, 11 menit CNSL mencapai $54,3 \%$ dan 13 menit, CNSL menurun menjadi $46 \%$.

Kacang mente yang diperoleh dengan perlakuan tersebut hanya pada daun lontar ada yang kuning, terjadi pada perlakuan pengukusan selama 13 menit dan penjemuran 16 jam, dan kacang mentenya utuh, sedangkan pada bahan bakar batang bambu kacang mente tetap putih dan utuh.

\section{KESIMPULAN}

Biji besar, prosentase minyak CNSL tertinggi yakni 78,3 \%, dengan bahan bakar daun lontar sebagai media bakar yang digunakan membakar biji mente, dengan perlakuan biji mente dijemur 8 jam. Terendah pada bahan bakar batang bambu, perlakuan 13 menit, penjemuran 16 jam, CNSL menurun menjadi $40 \%$. Kacang mente yang diperoleh dengan perlakuan tersebut hanya pada daun lontar ada yang kuning, terjadi pada perlakuan pengukusan selama 13 menit dan penjemuran 16 jam, dan kacang mentenya utuh, sedangkan pada bahan bakar batang bambu kacang mente tetap putih dan utuh.

Biji sedang, prosentase minyak laka terbanyak pada media bakar daun lontar untuk biji sedang, dengan tanpa perlakuan biji mente dijemur 8 jam menghasilkan prosentase CNSL pada kulit biji mente $75,3 \%$, kacang mente yang dihasilkan berwarna putih dan utuh. Terendah pada perlakuan tambahan berupah pengukusan, untuk pengukusan selama 9 menit dan dilakukan penjemuran 8 jam, CNSL 57,7\%, pengukusan 13 menit dengan penjemur 8 jam, CNSL yang terkadung menurun menjadi 42,3\%, kacang mente berwarna kuning.

Biji kecil, media bakar daun lontar tanpa perlakuan biji mente dijemur 8 jam menghasilkan prosentase CNSL pada kulit biji mente $74 \%$, kacang mente yang dihasilkan berwarna putih dan utuh. Sedangkan terendah bahan bakar batang bambu, perlakuan pengukusan 13 menit, CNSL menurun menjadi 38,7 \%. Kacang mente berwarna kuning pada pengukusan 9, 11, dan 13 menit dengan penjemuran 16 jam

\section{DAFTAR PUSTAKA}

[1]. Anonymous, 1998, "Teknologi Pengolahan Gelondong Mete, Liptan, Balai Pengkajian Teknologi Pertanian Ambon,Nopember 1998, 2 hal.

[2]. 2015, Petani Mete Cari Pasar Di Luar NTT, Antara News, Oktober

[3]. Bedy Sudjarmoko, 2010, Analisis Adopsi Teknologi Jambu Mete di Nusa Tenggara Timur, Bul. Littro. Vol. 21 No. 1, hal 69 - 79, Balai Penelitian Tanaman Rempah dan Aneka Tanaman Industri

[4]. Djokosetyardjo J. M., 2003, Ketel Uap, Cetakan Kelima, Jakarta, PT. Pradya Paramita

[5]. Hidayat Wahyu Marifka, 2015, “27 Ribu Warga NTT Jadi TKI dalam 4 Tahun Terakhir" Tempo, co, Selasa, 09 Juni 2015

[6]. Kreith Frank, Arko Projono Arko M.Sc., 1997, Prinsip-prinsip 
Perpindahan Panas, Edisi

Ketiga, Jakarta, Erlangga

[7]. Lukman Wawan, 2005, Teknik

Perbaikan Kualitas

Pengkacipan Buah Mente

dengan Pengukusan, Buletin

Teknik Pertanian, vol. 10 no.

1

[8]. Istirokhatun T., Wardhana Wisnu Irawan dan Primely, 2011, "Analisa Pengaruh Kelembaban Kayu Terhadap Konsentrasi Pm 2,5 Dalam Dapur Berbahan Bakar Kayu Skala Replikasi Dan Rumah Tangga"Jurnal Presipitasi, Vol. 8 No.1 Maret 2011, ISSN 1907-187X

[9]. Muljohardjo, M, 1991, Teknolodi dan Pengolahan Jambu Mete, Liberty, Yogyakarta

[10]Rismunandar, 1990, Memperbaiki Lingkungan dengan Bercocok Tanam Jambu Mede dan Avokat, Bandung, Sinar Baru, Cetakan Kelima

[11].Santoso, B., 1996, "Membuat Pengupas Biji Mente", Tilik Desa IV (140) : 5

[12].Yokasing B. Yohanes, 2014”, Upaya Mendapatkan Desain Mata Penyayat untuk Membangun Kacip Sesuai dengan Dimensi Kacang Mente di NTT", Laporan Hasil Penelitian Rutin (tidak dipublikasikan), Kupang, Politeknik Negeri Kupang 